\title{
Growth and yield of dry cultivated Capsicum frutescens plants under different doses of kinetin
}

\author{
Camila Lariane Amaro ${ }^{1}$, Diego Braga de Oliveira ${ }^{1}$, Patrícia Souza da Silveira ${ }^{1}$, Frederico da Costa M. Silva ${ }^{1}$, \\ Camila Lôrena Monteiro ${ }^{1}$, Leandro Mariano da Silva ${ }^{1}$, José Paulo Carneiro Custódio ${ }^{1}$, Fábio Santos Matos ${ }^{2}$
}

\author{
${ }^{1}$ Agronomy and Postgraduate Studies in plant production, the State University of Goiás (UEG), Brazil \\ ${ }^{2}$ Graduate Program in Plant Production of UEG, Câmpus Ipameri, highway GO 330, Km 241, ring road, university \\ sector, 75780-000-Ipameri, GO, Brazil
}

\section{*Corresponding author: fabio.agronomia@hotmail.com}

\begin{abstract}
The objective of the present study was to identify the effect of kinetin on Capsicum frutescens fruit yield. The research was carried out between October 2015 and September 2016 in the experimental field at the State University of Goiás, Brazil. This region has a tropical climate with a dry winter and wet summer. The experiment was conducted in rainy conditions (without irrigation) in a randomized block design with five treatments (plants submitted to $0,50,100,150,200$ and $250 \mathrm{mg} \mathrm{L}^{-1}$ kinetin in volume of 30 $\mathrm{ml} /$ plant/application in a total of two applications at a 40-day interval, started at the $\mathrm{R}_{2}$ reproductive stage), six replications and the plots consisted of two useful plants. The variables stomata density, specific leaf area, stem and canopy diameter, length and width of completely opened leaves did not fit the linear and quadratic regression models in function of the kinetin doses applied. Kinetin increased fruit drain strength and increased productivity of Capsicum frutescens. Plants treated with this cytokinin showed vigorous vegetative growth and significant increases in concentrations of photosynthetic pigments. The use of kinetin in Capsicum frutescens plants is a promising practice in the management of the species because it promotes morphophysiological adjustments in the plant that increase vegetative vigor and fruit yield.
\end{abstract}

Keywords: plant hormones, seasonings, pepper.

Abbreviations: $\mathrm{pH} \_$hydrogen ionic potential, M.O._organic matter, P_phosphorus, K_potassium, Ca_calcium, Mg_magnesium, Al_ aluminum, $\mathrm{H}+\mathrm{Al} \_$Hidrogen plus aluminum, CTC_ cataion exchange capacity, V\%_base saturation, $\mathrm{Chl} a+b$ leaf concentration of chlorophyll $a+b$, Car_carotenoids, Aw_wet tropical climate.

\section{Introduction}

The species Capsicum frutescens, popularly known as Capsicum frutescens, belongs to the family of the solanaceae, native to South America and cultivated in various regions of the world for use in seasoning, popular medicine, the pharmaceutical industry, ornamentation, in natura consumption and pest control (Pinto et al., 2013; Paulus et al., 2015). The Thai and South Koreans are the largest consumers in the world, ranging from 5 to 80g/person/day (Atui et al., 2014; Lima, 2014).

Pepper production in Brazil is concentrated on small farms with family labor. Pepper has significant social and economic importance because it requires a lot of hand labor, fixes the farmer in the field and is a profitable economic activity that integrates the small farmer with industry through conserves and sauces (Rufino and Penteado, 2006). In 2015, the area exploited with pepper in Brazil was approximately 5000 ha with total production of 75,000 tons (Pereira et al., 2015). The state of Minas Gerais is the largest Brazilian producer with about $70 \%$ of the total produced, but the biggest pepper consumers in Brazil are the north-eastern states (Ceará, Pernambuco and Bahia), especially for in natura consumption (Ribeiro et al., 2015).
Capsicum frutescens commercialized in natura has a $45-55 \%$ profit margin and expenses with hand labor correspond to $60 \%$ of the production cost (Embrapa, 2002; Embrapa, 2011). The profitability of producers capitalized with processing infrastructure can be increased with conserves, jellies, sources, cosmetics and ointments, but for farmers who commercialize the pepper in natura adopting innovative management practices seems to be the most viable alternative to increase yield and profitability.

Due to its medicinal and nutritional properties and the benefits promoted by vegetable peppers, promising practices need to be adopted to maximize yield and obtain satisfactory profitability. The use of plant regulators would be an excellent alternative to increase yield (Torres and Borges, 2013).

Growth regulators are natural or synthetic substances that when applied to plants have actions similar to natural hormones (Santos et al., 2016). The kinetin are a class of regulators that present effects on various physiological development processes, including leaf senescence, nutrient mobilization, apical dominance, meristem formation and activity (Taiz and Zeiger, 2013). Recent research has 
indicated growth regulator application to increase yield in several solanaceae species (Palangana et al., 2007; Gonçalves et al., 2013) to maximize germination and pepper seedling initial growth (Mohamadi et al., 2014). The use of regulators for various purposes has produced satisfactory results in different plant species (Greene et al., 2011; Matos et al., 2013; Costa and Silva et al., 2012; Torres and Borges, 2013). Nevertheless, there are few papers involving growth regulator application to Capsicum frutescens. Growth regulators have not usually been used as a management practice to intensify growth and yield of species of the genus Capsicum. In the few reports in the literature, kinetin are usually used in studies on embryogenesis in tissue culture (Gemes Juhász et al., 2009; Kim et al., 2008; Cheng et al., 2013).

With the object of using new technologies for commercial plantations allied to the development of new management practices to maximize yield, the objective of the present study was to identify the effect of kinetin on Capsicum frutescens fruit yield.

\section{Results and discussion}

The variables stomata density, specific leaf area, stem and canopy diameter and the length and width of fully opened leaves did not fit the linear and quadratic regression models in function of the kinetin doses applied.

Plant height presented quadratic growth in relation to the kinetin doses with the point of maximum height $(67 \mathrm{~cm})$ at the $115 \mathrm{mg} \mathrm{L}^{-1}$ dose. The carotenoid leaf concentration fitted the quadratic regression and the maximum point $\left(0.28 \mathrm{~g} \mathrm{~kg}^{-}\right.$ $\left.{ }^{1}\right)$ was at the $116 \mathrm{mg} \mathrm{L}^{-1}$ kinetin dose (Figure 2). The increase in height indicated that the Capsicum frutescens plants continued to grow in the reproductive period and the increased carotenoid concentration may have been as accessory pigment for the chlorophylls in capturing solar radiation to maximize photosynthesis and sustain the plant growth that occurred simultaneously with fruit swelling. The action of kinetin in embryogenesis, cell division and growth of plants of the genus Capsicum were reported in research by Cheng et al. (2013).

The total chlorophyll leaf concentration presented growing linear fit, because as the kinetin dose increased there were significant increases in chlorophylls $(a+b)$, so that under the largest kinetin doses these pigments were $44 \%$ superior to the control treatment. Fruit yield presented linear growth proportional to the kinetin dose applied, and under bigger kinetin doses the yield was $33 \%$ superior to the control treatment. When the increase in the kinetin doses no longer increased plant height, the accessory pigment concentration (carotenoid) decreased and the chlorophyll continued to increase parallel to the increase in fruit yield. The results indicated that increases of kinetin from $115 \mathrm{mg} \mathrm{L}^{-1}$ increased the fruit drainage force, which became priority in the importation of assimilates and the vegetative growth of the plant started to occur in a smaller magnitude. The plants treated with kinetin presented morphophysiological alterations in the photosynthesis machinery to adjust to assimilate production and fruit swelling (Borges et al., 2014). Figure 3 shows the principal components analysis. Axes 1 and 2 explained $58.7 \%$ of the data variation and demonstrated that there was no ranking of treatment groups in function of the doses applied. However, the increases in plant height, canopy diameter and yield in the same direction as Axis 1 indicated that fruit yield was directly related to plant vigor. Table 2 shows multiple regression to assess the effect of the variables analyzed on Capsicum frutescens fruit yield. Multiple regression explained $99 \%$ of the variation in Capsicum frutescens yield. The canopy diameter, leaf width and length were the determining variables for fruit yield. Ranking and multiple regression showed that the plant architecture, more specifically height and canopy diameter, together act as determining variables for leaf area (leaf width and length) of key importance in fruit yield in Capsicum frutescens plants. Principal component analysis and multiple regression together show that flowering and grain filling are processes that demand assimilated consumption largely produced in the leaves that need root system and stem developed for absorption and transport of soil solution according to Taiz and Zeiger, (2013). Plant hormone application altered Capsicum frutescens fruit growth, development and nutritional composition (Tiwari et al., 2012; Pérez Jiménez et al., 2015).

\section{Materials and methods}

\section{Plant materials}

The research was implemented in the rainy season and conducted between October 2015 and September 2016 in the experimental field at the State University of Goiás, Ipameri Campus (Lat. 170 43' 19" S, Long. 480 09' 35" W, Alt. $773 \mathrm{~m}$ ), Brazil. This region has a tropical climate with a dry winter and wet summer (Aw) according to the Köppen classification. The soil in the experimental area is classified as red yellow Latossol. The $\mathrm{pH}$ and fertilization were corrected after chemical analysis of the soil (Table 1) according to the technical recommendations for the crop proposed by Embrapa, (2007). The Capsicum frutescens seedlings produced on styrofoam trays were transplanted to the field when they were 30 days old.

The experiment was conducted in the rainy season without irrigation and randomized block design with five treatments (plants submitted to $0,50,100,150,200$ and 250 $\mathrm{mg} \mathrm{L}^{-1}$ of kinetin $\left(\mathrm{C}_{10} \mathrm{H}_{9} \mathrm{~N}_{5} \mathrm{O}\right)$ by volume of $30 \mathrm{ml} /$ plant / application for a total of two applications, the first on January 26, 2016 when $60 \%$ of the plants were under full flowering and the second 11 April 2016), six replications and the plot consisted of two useful plants. The fruits were collected as they ripened and yield was measured with the fresh fruits in natura in the same way as they are commercialized.

A the following variables were analyzed: plant height, stem and canopy diameter, length and width of fully opened leaves, chlorophyll and total carotenoid leaf concentrations, stomata density, specific leaf area and fruit yield.

During the experiment monthly climatic data of total rainfall, mean temperature and relative air humidity (Figure 1) were collected at the National Meteorological Institute at a station located $2 \mathrm{~km}$ from the experimental field. 
Table 1. Soil chemical characteristics, at the depth of 0 to $20 \mathrm{~cm}$ and 20 to $40 \mathrm{~cm}$, of the experimental area of the Campus of UEG-Ipameri/GO, Brazil.

\begin{tabular}{|c|c|c|c|c|c|c|c|c|c|c|}
\hline \multirow{2}{*}{ Profundidade } & \multirow{2}{*}{$\begin{array}{l}\mathrm{pH} \text { em } \\
\mathrm{CaCl}_{2}\end{array}$} & \multirow{2}{*}{$\begin{array}{l}\text { M.O. } \\
(\text { g.dm } \\
\text {-3) }\end{array}$} & \multirow{2}{*}{$\begin{array}{l}\text { P-Mehlich } \\
\left(\mathrm{mg}^{\left.-\mathrm{dm}^{-3}\right)}\right. \\
\end{array}$} & \multicolumn{6}{|c|}{ Complexo Sortivo $\left(\mathrm{cmol} \mathrm{dm}^{-3}\right)$} & \multirow[b]{2}{*}{ V\% } \\
\hline & & & & $\mathrm{K}$ & $\mathrm{Ca}$ & $\mathrm{Mg}$ & $\mathrm{Al}$ & $\mathrm{H}+\mathrm{Al}$ & CTC & \\
\hline 0 a 20 & 5,1 & 46,0 & 11,6 & 0,21 & 4.2 & 1,6 & 0,0 & 3,9 & 9,9 & 60,6 \\
\hline 20 a 40 & 5,1 & 31,0 & 6,7 & 0,17 & 3.8 & 1,1 & 0,0 & 3,7 & 8,7 & 57,8 \\
\hline
\end{tabular}

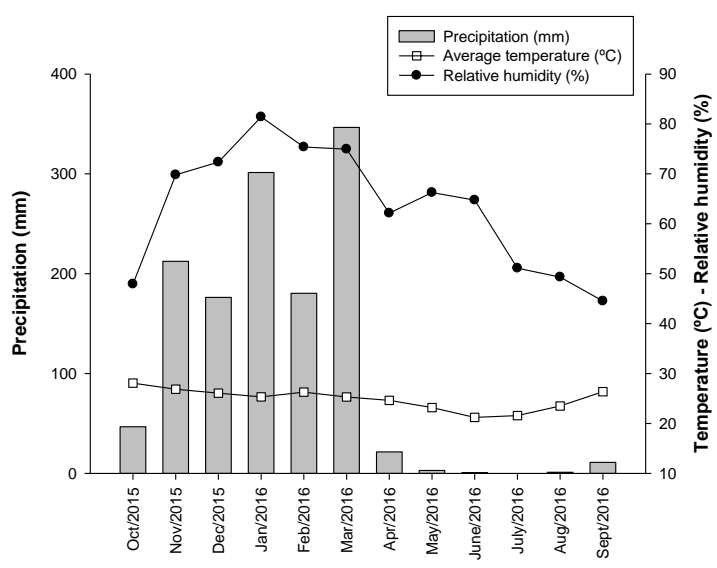

Months of the experimental year

Fig 1. Monthly climatic data of total rainfall, mean temperature and relative air humidity collected at a conventional meteorological station located $2 \mathrm{~km}$ from the experimental area.

Table 2. Multiple regression model to assess the effect of the variables on Capsicum frutescens plant productivity submitted to different kinetin doses.

\begin{tabular}{lcccccc}
\hline Produtividade $\left(\mathrm{kg} \mathrm{ha}^{-1}\right)$ & \multicolumn{2}{c}{$\mathrm{R}^{2}=0.99$} & $\mathrm{~F}(5.31)=2920$ & $\mathrm{p}<0.000$ \\
\hline & Beta & $\begin{array}{l}\text { Std.Err. } \\
\text { of Beta }\end{array}$ & $\mathrm{B}$ & $\begin{array}{l}\text { Std.Err. } \\
\text { of B }\end{array}$ & $\mathrm{t}(41)$ & $\mathrm{p}$-level \\
\hline Intercept & & & -5.191 & 1.228 & -4.225 & 0.000 \\
Altura & 0.025 & 0.013 & 0.033 & 0.017 & 1.898 & 0.066 \\
Diam. copa & 0.055 & 0.014 & 0.078 & 0.019 & 4.043 & $0.000^{*}$ \\
Larg. folha & 0.89 & 0.241 & 0.917 & 0.246 & 3.718 & $0.001^{*}$ \\
Comp. folha & -0.327 & 0.117 & -0.351 & 0.125 & -2.786 & $0.009^{*}$ \\
Car & 0.383 & 0.188 & 0.372 & 0.182 & 2.036 & 0.050 \\
\hline
\end{tabular}

${ }^{*}$ Significant at $1 \%$.
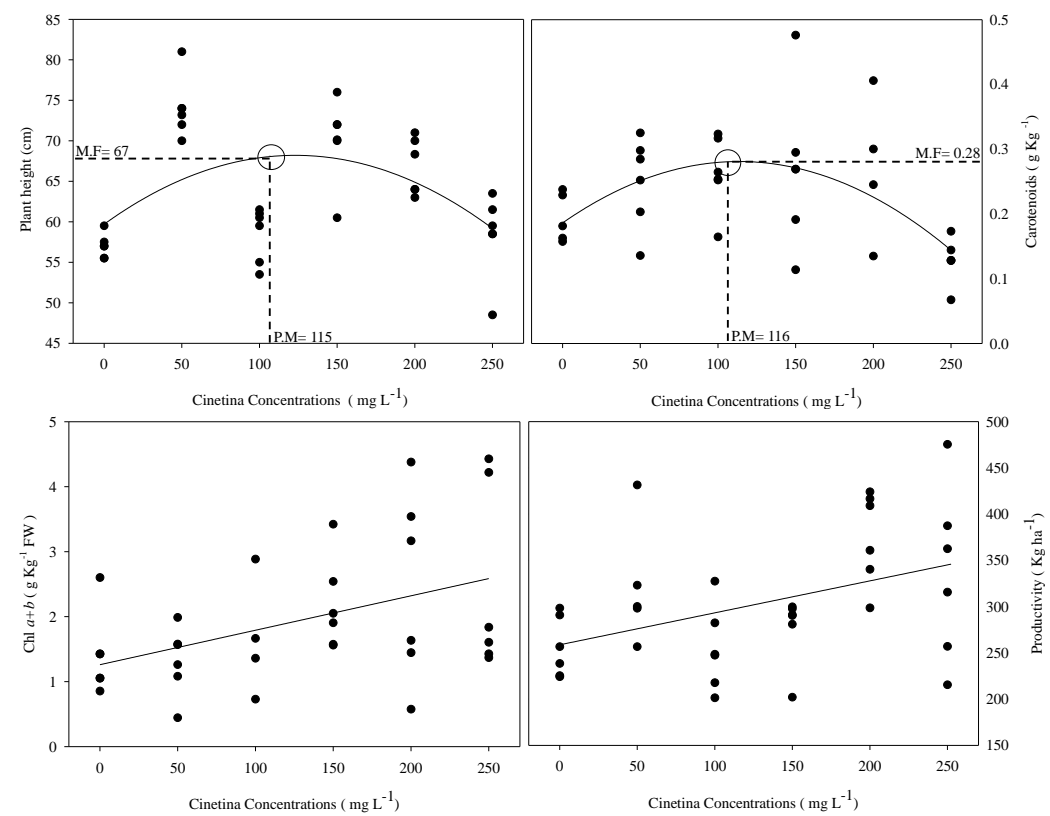

Fig 2. Regression equations for plant height $\left(y=59,7043+0,1381 x-0,0006 x^{2} ; R^{2}=0.99 *\right)$, carotenoids $(y=0,1861+0,0017 x-$ $\left.0,0000073552 x^{2}, R^{2}=0,92^{* *}\right)$, chlorophyll $a+b\left(y=1,2606+0,0053 x, R^{2}=0,82^{* *}\right)$ and yield $\left(y=258,7109+0,3455 x, R^{2}=0,96 *\right)$ of Capsicum frutescens plants treated with different kinetin doses. (Chl $a+b=$ chloropyll $a+b$ ). 


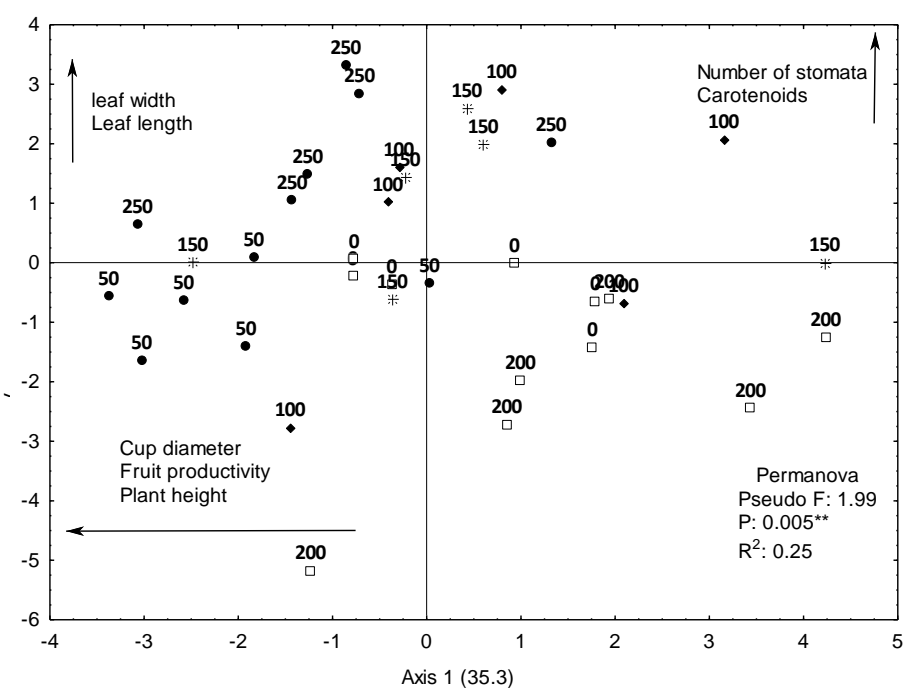

Fig 3. Principal component analysis for all variables analyzed in Capsicum frutescens plants treated with different kinetin doses.

\section{Physiological variables}

The number of leaves, stem and canopy diameter were measured using a graded ruler, tape measure and digital pachymeter. To obtain specific leaf area (SLA), six $12 \mathrm{~mm}$ diameter leaf discs were removed and from completely open leaves that were later dried in a chamber at $70^{\circ} \mathrm{C}$ for $72 \mathrm{~h}$ to determine the dry matter, the calculations were made following recommendations by Radford (2013). To determine the leaf concentrations of chlorophyll $(\mathrm{Cl} a+b)$ and total carotenoids, two leaf discs were removed (third to fifth pair of completely open leaves) of known area and placed in jars containing dimethyl sulfoxide (DMSO). Later extraction was made in a water bath at $65^{\circ} \mathrm{C}$ for four hours. Aliquots were removed for spectrophotometer reading at 480, 646 and $665 \mathrm{~nm}$. The chlorophyll $a(\mathrm{Cl} a)$ and clorofila $b$ $(\mathrm{Cl} b)$ chlorophyll contents were determined following recommendations by Wellburn (1994).

\section{Morphological variables}

The morphological variables were analyzed 20 days after the last growth regulator application. To assess the stomata density, replications of leaf adaxial and abaxial surfaces were made with colorless nail polish in the middle third region of previously dehydrated leaves. The stomata were counted using an optical microscope equipped with a light chamber. The stomata density was determined by counting the stomata situated in a $1 \mathrm{~mm}^{2}$ area (Jadrná et al., 2009). Five replications of both the adaxial and abaxial surfaces were analyzed from each replication to determine the stomata density. Fruits were collected when ripe and yield was measured by weighing the fruits in natura, in the same way as they are commercialized.

\section{Statistical procedures}

The variables were submitted to analysis of variance and linear or quadratic regression according to a randomized block design with five treatments and six replications. Multivariate analyses were made using the main components technique using a correlation matrix and the selection criteria of the axes by Broken Stick coupled to multivariate analysis of variance by permutation PEMANOVA (Anderson, 2001).

Multiple regression analysis was used to assess yield using the forward stepwise selection model (Sokal e Rolf, 1969). The R software was used to carry out these analyses ( $\mathrm{R}$ Core Team, 2017).

\section{Conclusion}

Kinetin increased fruit drain strength and increased productivity of Capsicum frutescens. Plants treated with this cytokinin showed vigorous vegetative growth and significant increases in concentrations of photosynthetic pigments. The use of kinetin in Capsicum frutescens plants is a promising practice in the management of the species because it promotes morphophysiological adjustments in the plant that increase vegetative vigor and fruit yield.

\section{References}

Anderson MJA (2001) New method for non-parametric multivariate analysis of variance. Aust Eco. 26: 32-46.

Atui F, Ribeiro C (2014) Pimentas ajudam a aliviar a dor e diminuir inflamação no organismo. http://g1.globo.com/bemestar/noticia/2014/03/pimentasajudam-aliviar-dor-e-diminuir-inflamacoes-noorganismo.html. Available at: Acess: April 19, 2017.

Borges LP, Torres Junior HD, Neves TG, Cruvinel CKL, Santos PGF, Matos FS (2014) Does benzyladenine application increase soybean productivity. Afr J Agric Res. 9 (37): 27992804.

Cheng Y, Ma R, Jiao YS, Qiao N, Li TT (2013) Impact of genotype, plant growth regulators and activated charcoal on embryogenesis induction in microspore culture of pepper (Capsicum annuum L.). S Afr J Bot. 88: 306-309.

Costa and Silva ATV, Neves TG, Zucchi MR, Rocha EC, Matos FS (2012) Avaliação da senescência foliar de plantas de Jatropha curcas $\mathrm{L}$. submetidas a doses de benziladenina. $\mathrm{R}$ Agrotec. 3(1): 01-19. 
Empresa Brasileira de Pesquisa Agropecuária (2011) As novas variedades de pimenta da Embrapa e o mercado pimenteiro: oportunidade de renda para agricultores. Available at: http://hotsites.sct.embrapa.br/prosarural/ programação/2011/cultivares-de-pimenta-maisresistentes-e-produtivas-1. Acess: April 19, 2017.

Empresa Brasileira de Pesquisa Agropecuária (2007) Pimenta (Capsicum spp.). Available at: https://sistemasdeproducao. cnptia.embrapa.br/FontesHTML/Pimenta/Pimenta capsic um spp/processamento.html. Acess: April 18, 2017.

Gémes Juhász A, Kristóf Z, Vági P, Lantos C, Paul J (2009) In vitro anther and isolated microspore culture as tools in sweet and spice pepper breeding. Acta Hortic. 829: 61-64.

Gonçalves CX (2013) Alterações moleculares, físico químicas e fisiológicas em melões e tomates: relações com etileno e citocininas. (Dissertação Mestrado). Universidade Estadual de Pelotas, Pelotas. 133

Greene DW, Schupp JR, Winzeler HE (2011) Effect of abscisic acid and benzyladenine on fruit set and fruit quality of apples. Hort Sci. 46 (4):604-609.

Jadrná P, Kobza F, Plavcová O (2009) Polyploidization of Pelargonium $x$ hortorum L. H. Bailey in greenhouse conditions. Hortic Sci. 36 (1):31-37.

Kim M, Jang IC, Kim JA, Park EJ, Yoon M, Lee Y (2008) Embryogenesis and plant regeneration of hot pepper (Capsicum annuum L.) through isolated microspore culture. Plant Cell R. 27: 425-434.

Lima JME, Smiderle OJ (2014) Qualidade fisiológica de sementes de pimenta obtidas em frutos de diferentes maturações e armazenadas. Semina. 35 (1): 251-258.

Matos FS, Ribeiro RP, Borges LP, Neves TG, Cruvinel CKL, Freitas RG (2013) Aplicação de benziladenina em plantas de pinhão manso. R Agrotec. 4(2): 57-67.

Mohamadi ZM, Talebi M, Sayed-Tabatabaei BE, Khaksar G (2014) Effect of explants, hormonal combination and genotype on micropropagation of pepper. J Sci Tech G Cult 5 (2): 95-106, 2014.

Paulus D, Valmorbida R, Santin A, Toffoli E, Paulus E (2015) Crescimento, produção e qualidade de frutos de pimenta (Capsicum annuum) em diferentes espaçamentos. Hortic Bras. 33: 91-100.

Pereira IS, Barreto FZ, Balsalobre TW, Sala FC, Costa CP, Carneiro MS (2015) Validação de marcadores moleculares associados à pungência em pimenta. Hortic Bras. 33: 189195.

Pérez-Jiménez $M$, Pazos-Navarrob $M$, López-Marína J, Amparo Gálveza A, Varóc P, Del Amora FM (2015) Foliar application of plant growth regulators changes the nutrient composition of sweet pepper (Capsicum annuum L.) Sci Hortic. 194(14):188-193.
Pinto CMF, De Oliveira Pinto CL, Donzeles SML Pimenta (2013) Capsicum: propriedades químicas, nutricionais, farmacológicas e medicinais e seu potencial para o agronegócio. Rev Bras Agropec Sustent. 3(2):108-120.

Radford, PJ (2013) Growth analysis formulae: their use and abuse. In: Nakazono EM, Costa MC, Futatsugi K, Paulilo MTS (ed) Análise comparativa de crescimento entre genótipos de pimenta cultivados em casa de vegetação. Biosci J. 29(1):125-131.

R Core Team, R: A language and environment for statistical computing, R Foundation for Statistical Computing, Vienna, Austria. Available at: http://www.R-project,org/. Acess: April 18, 2017.

Ribeiro AC, Guimarães PTG, Alvarezv HV (1999) Recomendações para o uso de corretivos e fertilizantes em Minas Gerais - 5a Aproximação. 1th edn. Viçosa.359.

Ribeiro CSC, Henz GP, Vilela NF, Amaro GB, Melo WF, Rufschneider FJB. Árvore do conhecimento pimenta. Available http://www.agencia.cnptia.embrapa.br/gestor/pimenta/A bertura.html. Acess: April 10, 2015.

Rufino JLS, Penteado DCS (2006) Importância econômica, perspectivas e potencialidades do mercado para pimenta. R Inf Agropec. 27 (235):7-15.

Palangana FC, Silva ES, Goto R, Ono EO (2012) Ação conjunta de citocinina, giberelina e auxina em pimentão enxertado e não enxertado sob cultivo protegido. Hortic Bras. 30(4): 751-755.

Santos EO, Rodrigues AAJ, Da Silva ER, De Carvalho ACPP (2016) Multiplicação de bastão-do-imperador em resposta a concentrações de BAP e número de subcultivos. Orn Hortic. 22(1): 88-93.

Sokal RR, Rohlf FJ (1969) The principles and practice of statistics in biological research: WH Freeman and company. 4th edn. San Francisco 222-223.

Taiz L, Zeiger E (2013) Fisiologia vegetal. 5rd edn. ArtMed. Porto Alegre: 954.

Tiwari A, Offringa R, Heuvelink EP (2012) Auxin-induced Fruit Set in Capsicum annuum L. Requires Downstream Gibberellin Biosynthesis. J Plant Growth Regul. 31:570578.

Torres RC, De Souza Borges KCA (2013) Ação da giberelina no crescimento de pimenta (Capsicum frutescens). Cadernos UniFOA (1):11-16.

Wellburn AR (1994) The spectral determination of chlorophylls $a$ and $b$, as well as total carotenoids, using various solvents with spectrophotometers of different resolution. J Plant Physiol. 144(3): 307-313. 